\title{
Emmanuel Droit Writing a global history of 1989
}

\author{
Between a shock wave and a gap in time
}

\begin{abstract}
The year 1989 was unquestionably a global event. Writing a global history of 1989 is a challenge that requires reconciling spatial intercontinental distance and the capacity of actors to gain awareness of the "planetarity" (Spivak 2003) of historical processes. This article is a programmatic essay that attempts to grasp such transnational and global dynamics, such as the "Gorbachev factor" and the shared historical experience of a "breach in time" by undertaking a multisited analysis. ${ }^{1}$
\end{abstract}

Keywords: global, event, planetarity, experience, multi-sited

\section{1989: a Leviathan of events}

Both domestically in many states and internationally, 1989 was an année évenementielle a year filled with events of even greater number and scope than 1968 (see Brown 2012; Bantigny et al. 2017; Bantigny 2018) or 1973 (see Compagnon and Moine 2015). Under the combined effects of accumulating events immediately deemed "historic" and of the acceleration of historical time, affecting the everyday lives of millions of individuals, each season of 1989 came with its "carnival of revolutions" (Kenney 2003), ends of wars, and more or less peaceful political transitions in Eastern Europe, Latin America, Asia, and Africa.

The year 1989 saw the end of military dictatorships in Paraguay and Chile, the bloody crackdown on the student movement in China, the historic encounter between Mandela and Botha in South Africa, and the latter's resignation and replacement by Frederik de Klerk, the collapse of Communist states in Eastern Europe, the failed coup in Ethiopia, the Vietnamese popular army's withdrawal from Cambodia, the end of the Sandinista revolution in Nicaragua, the US invasion of Panama, Benin's abolition of Marxism-Leninism as an official ideology, George

1 This chapter was translated from the original French by Jean-Yves Bart, with support from the Maison Interuniversitaire des Sciences de l'Homme d'Alsace (MISHA) and the Excellence Initiative of the University of Strasbourg.

Emmanuel Droit, Sciences Po Strasbourg

2 Open Access. (c) 2021 Emmanuel Droit (c) BY-NC-ND This work is licensed under a Creative Commons Attribution-NonCommercial-No-Derivatives 4.0 License. https://doi.org/10.1515/9783110691504-009 
Bush and Mikhail Gorbachev's declaration that the Cold War was over at the end of of the Malta Summit: all of these events lent 1989 an exceptional density.

These "volcanoes of topicality" (Nora 1972, 164) erupted spectacularly across the entire world. Like the fall of the Berlin Wall and the Romanian revolution, these events were broadcast, manufactured, or anticipated by television cameras. The international events of 1989 continue to fascinate the media due to their groundbreaking power. Their succession and dissemination in a variety of places across the world are also intriguing for historians, since they involve innovation, breakdowns, and uncertainty. These events were also experienced with varying degrees of intensity depending on geographical location and country. While 1989 in the European context was obviously a key year and an experiential gap for Eastern Europe, this was far less so the case for Western Europe (see Mark and Rupprecht 2017, 224-249).

How are we, then, to give a global meaning (see Dakowska 2009, 3-4; Kenney and Horn 2004; Engel et al. 2014; Middell 2015, 171-184; Rupnik 2014) to this multitude of events rooted in international, national, or regional contexts? What methodological conditions and conceptual tools are needed for a global history of 1989 ?

This exploratory research programme I sketch in this article takes issue with the idea that "the year 1989 has ceased to be an object of reflection" (Grosser 2009, 9). First, it requires moving beyond the all-encompassing, Western universalist approach to 1989 developed by the first early philosophical and historical analyses. Further, having clarified the conditions needed for writing a global history, this reflection will explore two planetary dimensions of 1989 drawing on 'local' archives allowing us to grasp transnational dynamics: first, the shock wave sent by the "Gorbachev factor", which shattered a bipolar order that had already been challenged for some years, and second, the shared experience of a "gap in time" (Arendt 1961). In this chapter, I have chosen to draw on the GDR archives (East Germany) on the grounds that this Socialist regime works as a lens through which to observe globality, insofar as it was fully part of a variety of processes that took on an extended spatial scope.

\section{9 and the illusion of an all-encompassing Western universalist approach}

In the wake of this "year when the world turned upside down” (Grosser 2009, 9), the West German weekly newspaper Die Zeit began the new decade with a piece entitled “Golden Nineties?”. Hinting at some uncertainty, the question mark almost 
seemed to suggest rhetorical effect, since the writer was brimming with optimism and indeed confident of a serene, radiant future - at least for Europe: "In Europe, boundless optimism prevails" (Die Zeit, 1990). This perception was broadly shared by those Western thinkers who made the first attempts at interpreting 1989, in some cases at times when the year's “monster events" (Nora 1972) were still unfolding.

These Western-centric interpretations, written quickly between the spring of 1989 and the early months of 1990 by philosophers and sociologists, such as Francis Fukuyama and Ralf Dahrendorf, laid the bases for more or less optimistic (Mearsheimer 1990, 5-56)2 ${ }^{2}$, more or less heroic narratives, which shared this idea of completion, finitude. These attempts to give a global meaning to history as it was happening reflect a perception of the geopolitical environment in the form of what German historian Martin Sabrow termed "experiential breaks". ${ }^{3}$ These should be distinguished from the interpretative breaks introduced retrospectively by historians, which allow them to divide history into periods.

These experiential breaks should be put into perspective in a comparative history approach, as other surges of optimism or honeymoon periods emerged at various other times in the twentieth century $(1918,1945)$. By April 1989, Francis Fukuyama had already announced "the end of History" (1989, 3-18) in the sense that he saw 1989 as the fulfillment of the Western universalism that had appeared in 1789. A year later, in an open letter addressed to a Polish friend who worried about the post-revolutionary future, Dahrendorf wrote that the conditions were met for political and economic liberties to thrive in Europe (see Dahrendorf 2004). As they sought to subsume different events under a heroic dramatization of the triumph of the West and its values, these founding narratives (Meistererzählungen in German) fell prey to a universalist and teleological temptation. Above all, they expressed a universalist, all-encompassing vision of history, which in part resurfaced in 2009 during the celebrations on the occasion of the twentieth anniversary of the fall of the Berlin Wall. Polish poet and essayist Stanisław Baranczak even went already in the early 1990s so far as to turn 1989 into a 'quasi-metaphysical' event, calling it an Annus Mirabilis:

a year of instant gratification for all the impossible dreamers and incorrigible believers in the final triumph of right over might [...] What had seemed totally out of the question for decades, could prove entirely feasible a minute later. And the wildly increasing speed of it all! In the history of mankind there had been, I guess, no comparable period of such dizzying acceleration of crucial changes (Barancz 1990, 5).

2 In the summer of 1990, political scientist John Mearsheimer wrote, with a tinge of concern, that 1989 marked the end of a "long peace" resting on a "military balance".

3 Sabrow (2013) proposed the concept of "experiential break" to refer to a break experienced as such by contemporaries as opposed to a break defined ex post by historians. 
A critical history of the present time should approach these Hegelian or 'divine' theories as seismographs, as outliers reflecting Western-centric ways of rethinking a post-Cold War regime of historicity. The point of elaborating a global history of 1989 is not to unveil the operation of some rationality that would lead to the fulfilment of Western liberalism in the political and economic fields. In this sense, it must also reconsider and historicize the way in which political science research has used the transformation paradigm to explain the trajectories of European post-socialist countries (see Berend and Bugaric 2015, 768-785). At the same time, the Eastern European narrative on the 'return to Europe' (primarily seen as a return to the pre-Communist order of 1919) and the 'return of history' (Rupnik 1992, 53-60) should also be deconstructed, as Communist dictatorships never entirely froze, so to speak, the development of Eastern European societies or national sentiments. ${ }^{4}$

Beyond an awareness of a number of pitfalls, the writing of the global history of such an event-filled year requires a significant effort of epistemological clarification. Indeed, despite the success of the "global turn" label, this method for writing history has been struggling to clear up its goals and methods in the past few years (see Drayton and Motadel 2018, 1-21). What then are the theoretical and practical heuristic implications of such a global history?

\section{9 and the challenge of writing global history}

Writing a global history of 1989 first entails adopting a rigorous epistemological position on what this historiographical practice means. Such clarification efforts have over the past few years largely been undertaken by French political scientists like Karoline Postel-Vinay (2014, 25-33) and German historians specializing in Asia such as Jürgen Osterhammel $(2017,89)$ or Sebastian Conrad (2017).

Applying global history to $1989^{5}$ should not, therefore, lead us to attempt to write the story of everything: global history is neither a synthesis of syntheses nor a 'catch-all' concept to replace the practices of comparative history, the history of cultural transfers, connected history or histoire croisée... ${ }^{6}$ Too often advertised,

\footnotetext{
4 Regarding the case of Poland, see Zaremba (2001).

5 For Angela Siebold's recent programmatic proposal, see Siebold (2019).

6 In this sense, I am clearly positioning myself against the approach presented by Chloé Maurel in her 2013 historiography paper on global history (see Maurel 2013, 13-19). Global History cannot be considered as a general label that embraces different kinds of approaches such as comparative history, transnational history...
} 
but rarely actually applied, this approach must avoid two main methodological pitfalls.

The first pitfall consists in conflating global history and the history of globalisation by falling into the trap of what Sebastian Conrad calls "teleology of globalisation rhetoric" (Conrad 2017, 212): the global history of 1989 should not be reduced to the analysis of the mechanisms of integration and ever denser interdependence between polities, economies, and societies on a global scale. Examining issues related to the transformations of capitalism, the digital revolution, or the environment is not enough to trace the outlines of a global history of 1989.

The second pitfall is that of the retrospective approach frequently found in Western historiography. Despite the suddenness of the event, 1989 is rarely seen as the actualization of one possibility among others, but first and foremost as the end point of a politically illegitimate experiment tainted by economic failure, whose demise had been marked by a series of historical stages in Eastern Europe: June 17, 1953 in the GDR, 1956 in Poland and in Hungary, 1968 in Czechoslovakia, 1980 in Poland. Ultimately, the '1989' event is presented as the final milestone in a mechanic chain of causality, and each national crisis within the Eastern block is supposed to reflect the ever-growing political illegitimacy and manifest economic inefficiency of Communism (see Bispinck et al. 2004). This representation of historical temporality stifles critical thinking on the effects of the political continuity of Communism in regions outside Europe (e.g. in Cuba, Vietnam, China).

The very notion of a fundamental break deserves reexamination, and various efforts at critical reconsideration have emerged in Germany. German historians of the present have been careful to question the chronological markers that legitimate their sub-discipline (see Droit 2014, 167-181), and do so at regular intervals: after 1917, 1933, and 1945, 1989's turn has come.

Social historian such as Anselm Doering-Manteuffel and Lutz Raphael have suggested moving the cursor, and replacing 1989 with the early 1970s, which they view as a key juncture. They contend that structural economic changes have gradually transformed societies in decisive ways (see also Doering-Manteuffel and Raphael 2008). This social approach is currently being expanded upon at the Potsdam Centre for Contemporary History by a socio-cultural history project on the long transformation of the two Germanies, involving a team of German historians led by Kerstin Brückweh. Working in an international and political history approach, Frank Bösch, too, argues that 1989 should be replaced by another year, but proposes 1979 instead. He describes it as a global year, marked by the Shiite Revolution in Iran, the beginning of the war in Afghanistan, and the prominent coverage given to Vietnamese boat people, and thus as the "prehistory of the conditions of our present time" (Bösch 2019). 
A global history of 1989 should be aware of these traps and combine distance and awareness. It should not be disconnected from the micro level; on the contrary, it can only be envisioned by investigating venues where large-scope interactions occur and actors embedded in distinct local configurations (see Bertrand and Calafat 2018, 1-18).

More precisely, the global history of 1989 should account both, for intercontinental spatial (political, economic, and cultural) distance, and for the capacity of actors to bridge that distance by developing an awareness of the "planetarity" (see Spivak 2003, 71-102) of an event, an idea, an actor or process (see Chartier 2001, 119-123). Since the nineteenth century, at least, thinking and acting globally is no longer the preserve of a minority of privileged cosmopolitan elites (Frank 2012, 47-70). Since the entry in the modernity, more and more men and women have broadened the scope of their thought and actions. This awareness may spark a need for imitation, rejection, or simply elicit passivity. Thinking and acting globally, therefore, entails overcoming the limitations of spatial distance and associating oneself with what is happening "over there". This experience should be understood in a multi-sited manner, following a synchronic approach to historical processes allowing to unveil their overlap and changes in local configurations. ${ }^{7}$ This would require actually compiling corpuses of polyphonic sources consisting of historical materials from different parts of the world, and approaching them from a global perspective. Of course, this clearly raises very practical issues, not least of linguistic proficiency and access to archives, and points to the need of testing collaborative forms of writing.

Drawing on these theoretical premises, historians must evidence loci for the observation of this possible multi-sited global history of 1989. For the purpose of weaving together geographical distance and awareness, one possibility is to define an epicenter, i.e., a locus that is capable of producing a process of differentiated dissemination and reactions within a very short time span. This locus can, for instance, be embodied by a state, an institution, or a political actor embedded within a configuration of power. In the following, I suggest that zooming in on Mikhail Gorbachev (and his advisers, the CPSU's political bureau) may be one such relevant illustration of the rewards of a global history of 1989.

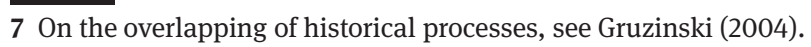




\section{The shock wave of the "Gorbachev factor"}

By committing to ending the bipolar order and sacrificing the USSR's 'Empire', the international policy of Mikhail Gorbachev's team undeniably resonated globally. Certainly, the varying impacts of this 'Eastern wind' in Europe, Africa, and Latin America should be precisely assessed. Still, decisions made in this Soviet epicenter quickly required Western policy-makers to face the consequences of this fluid international situation and Communist regimes worldwide to consider the question of how they could stay in power. Under the effect of the shock wave of the "Gorbachev factor", they had to address the following question: Should they pick violence and repression to stay in power (the 'Chinese solution') or agree to a gradual, negotiated sharing of power (the 'Polish solution')?

\subsection{A driver of global instability}

On March 10, 1985, after the announcement of Constantin Chernenko's death, Mikhail Gorbachev walked in his dacha's garden alongside his wife Raisa. In his memoirs, he paints the picture of a political 'Big Bang' of sorts: “You see, I came here with the hope and belief that I could get something done, but so far there has been very little to show for it. If I really want things to change, I must accept the offer, if indeed there is one of course. We can't go on living like this” (Gorbatchev 1997, 218).

A few days later, he became the CPSU's First Secretary. This position of power within the state apparatus ${ }^{8}$ was going to allow him to implement a new policy on the scale of both the exterior and interior Empire with support from the KGB. Given the growing interdependence of the "Socialist camp" since 1956 and ties that were therefore considered strong enough, Gorbachev believed that regenerating the Soviet model was going to breathe new life into the Communist bloc. Faced with the urgent need to fund his economic reforms, the new First Secretary was no longer in favor of a closed, hyper-militaristic regime. He had already asserted his commitment to international cooperation and to the construction of a "consensus of all mankind" (Gorbatchev 1988).

This loosening in the use of force to retain the external Empire (see Gorbatchev 1997, 584-590) was a driver of global instability, ultimately giving way to the peaceful dissolution of both the external and the internal Empire. This

8 On Stalin, see Khlevniuk (2008). Concerning the older tradition of personal domination, see Zakibi (2006). 
reorientation was quickly perceived by some Communist leaders as a threat. During a press conference at the Gorbachev-Castro summit of April 1989, a Chilean reporter asked what advice the "genius" Gorbachev could give to Cubans. Fidel Castro ironically retorted that "Mr. Gorbachev's genius precisely consists in not giving advice". 9

The impending demise of the Brezhnev doctrine posed a dilemma for Communist leaders - what were they going to do? Follow in the path of their "Soviet big brother" or turn their backs? How would they react if their own society no longer toed the official line? Two main responses to the shock wave triggered by the "Gorbachev factor" emerged (Brown 1997): the 'Chinese solution' and the 'Polish solution'.

\subsection{A range of possibilities, between the 'Chinese solution' and the 'Polish solution'}

The phrase 'Chinese solution' was coined in the Fall of 1989 in East German opposition movements to refer to the potential use of force by the Communist Party's executive bodies. Signs during the first demonstrations read: "No Chinese solution for the GDR!" (Holm 2017). Indeed, the option picked by the leadership of the Chinese communist party to crush the student uprising of June 1989 had sparked worldwide outrage. Western media sources described it as a "bloodbath" (INAArchives 1998) and a "night of terror", and similar outrage also prevailed in Eastern European civil societies. In the GDR and Poland, churches became venues for the expression of solidarity with Chinese students and protests. ${ }^{10}$ Rallies were staged in front of the Chinese embassy and Air China's offices in East Berlin, and a band called Herbst in Peking (Autumn in Beijing) was formed. ${ }^{11}$ In a note to Erich Honecker, sent from Beijing on 14 July 1989, Gunter Schabowski, a member of the political bureau, quoted Jiang Zemin's words to point out what he saw as the restraint displayed by the Communist Party of China: "Where in the world can one

\footnotetext{
9 Stiftung Archiv der Parteien und Massenorganisationen der DDR im Bundesarchiv (SAPMOBarch), the original German reads: "Büro Erich Honecker, DY 30/2462, Beziehungen zu Cuba, Vermerk über das Gespräch Honecker/Jorge Risquet, Mitglied des Politbüros und Sekretär des ZK der KP Kubas, 17.04.1989” (English translation: “Office Erich Honecker, DY 30/2462, Relations to Cuba, Note on the conversation Honecker/Jorge Risquet, Member of the Politburo and Secretary of the Central Committee of the Communist Party of Cuba, 17 April 1989").

10 Archive of the Robert-Havemann-Society, Protest letter against the brutal proceeding of the Chinese Government in Peking, 5 June 1989.

11 Bundesbeauftragte für die Unterlagen der Staatssicherheit der ehemaligen DDR (BStU), Zentralarchiv (ZA), Hauptabteilung II, 26979.
} 
find examples of the main political square being occupied for such a long time by antagonistic forces?" 12

The 'Chinese solution' was the outcome of an unequal balance of power within the political bureau, which made the crackdown a possible political response to protesters' demands for reform. This was a rational option picked by the bureau's majority branch, led by Deng Xiaoping, and opposed to the Party's General Secretary Zhao Ziyang. It was seen as a way to continue combining economic openness and ideological strictness, as Zhao Ziyang explained to Erich Honecker during an official meeting in East Berlin on June 8, 1987: "We should take care to both continue the policy of reforms and the opening to the outside and to take into consideration influences from the outside... We do not think autarky is a good method to protect citizens from foreign influences."13 This kind of solution was monitored closely by East German and Romanian leaders, who initially took the political risk of officially supporting the Chinese leaders, even if it meant damaging their image internationally, insofar as Westerners viewed this support as surprising and immoral. In the GDR itself, fears surfaced about a possible implementation of the 'Chinese solution'.

Ultimately, the excessive use of force and the international outcry sparked by the Chinese repression put popular democracies in an increasingly defensive position, narrowing their range of responses to the collective protests of the fall of 1989 (Schäfer 2012, 153-172). This turn towards discipline, linked to Tiananmen, was also perceptible in Gorbachev's methods of action. Having endorsed the use of force in Georgia in the winter of 1989, he then showed himself more reluctant to do it again to prevent the USSR's disintegration process (Jian 2009, 96-131). Also, the introduction of economic sanctions against China, especially by the Federal Republic of Germany, served as a reminder that the use of force was not worthwhile in the short run in terms of international image.

The complete opposite of the 'Chinese solution', the 'Polish solution' refers to a peacefully negotiated process of transition from dictatorship to democracy. Until the fall of 1989, most Western observers (including West German experts like Elisabeth Weber) were surprised to see that the transition away from State com-

12 SAPMO-Barch, DY 30/2437, Office Honecker, Relations with China “Blitznotiz” by Gunter Schabowski to Honecker (he is in China), July 14, 1989, 165.

13 SAPMO-Barch, DY 30/2437, Stenographic Transcription of the official conversations of the Secretary General of the Central Committee of the SED and the Chairman of the State council (Vorsitzender des Staatsrates) of the GDR with the Secretary General of the Central Committee of the Communist Party of China and the Ministerial President of the State Council of the People's Republic of China (Ministerpräsidenten des Staatsrates der VR China), Zhao Ziyang, June 8, 1987, in Berlin, 17. 
munism that had begun with the round table of February 1989 was happening without violence. Even the skilled practitioner of Détente, Gunter Haus, the West Germany's permanent representative in the GDR, believed that the peaceful dissolution of the Eastern Bloc was a utopian prospect, if not risky and impossible to implement (Borodzej 2009, 278-303).

Since its inception in 1944, the history of Communist Poland had been marked by episodes of violence, combining protests against the State and workers' revolts (1956, 1970, 1976, 1980/1981). Even though the Polish political authorities never entirely discarded the option of force, the choice of a gradual transition away from dictatorship without a revolution allowed Poland to experience a peaceful process. In a meeting with Honecker on May 22, 1989 in East Berlin, Jaruzelski stressed that "the Party has made a profound analysis of the situation and found that it will not be able to solve emerging and outstanding problems with the old methods... In the past, in the years 1956, 1970, 1980, changes had been brought about through coercion by large-scale social shocks" ${ }^{14}$ The Polish head of state concluded by drawing a parallel with 1918 and the peace of Brest-Litovsk: to save Communism, one must compromise and accept the rule of political pluralism.

The "Gorbachev factor" was primarily geopolitical in nature: the USSR no longer intended to resort to Brezhnev's doctrine of limited sovereignty. To save the internal empire and implement its reforms, the Soviet leader gave up on intervening within his protective glacis, thus triggering a "carnival of revolutions", which, except in Romania, was essentially a peaceful process: being incapable of bringing their social and economic project to fruition, the Communist elites ended up surrendering power without offering much resistance, including in countries that were less open to reformism, like the GDR and Czechoslovakia. As the last president of the Hungarian socialist party, Karel Grosz, noted in 1991: "Parties were not overthrown by opposition forces but - paradoxically - by their own executives". This view has since been supported by the fine-grained historical analysis of US historian Stephen Kotkin, who denounced the "utopia of civil society theory" $(2009,7)$. Kotkin argued that revolutions were spurred by unstructured mass movements, not civil societies, for the simple reason that there were no civil societies yet at the time.

While the "Gorbachev factor" had a very strong impact in the European countries that formed the USSR's 'protective glacis', the African continent was not out of reach for this shock wave. Although the transcontinental and global history of 1989 extends to all continents with a different intensity, the African continent offers a particularly productive case. How does Africa fit within a global history of 1989 ?

14 SAPMO-Barch, DY 30/2479, Volume 4: 1984-1989, 355 and 364. 


\subsection{A ripple effect on the African continent}

In the late 1970s, Western experts became increasingly concerned about the inexorable progression of Soviet influence on the African continent. The direct or indirect (through the commitment of Cuban forces) military support, and the economic and technological aid granted to Benin, Ethiopia, Libya, Angola, and Mozambique were presented in Moscow as evidence of a shift in the international balance of power and a prelude to the worldwide victory of socialism. On February 2, 1989, during a conversation with Volonia Teitelboim, a member of the secretariat of the Chilean communist party's central committee, Erich Honecker pointed out that the military support offered by Cuban troops against the South African army had allowed to stabilize Angola, Mozambique, and to further the independence of Namibia. ${ }^{15}$

In Africa, as in Central and Eastern Europe, the "Gorbachev factor" led to a disengagement of Soviet power and to a political and geopolitical reconfiguration. However, the influence of the "Eastern wind" should not be overstated, as the democratic surge in Africa (in Algeria, Tunisia, South Africa, Burkina Faso) certainly had a greater impact than the "carnival of revolutions" in the East. In 1989, Benin, which had been ruled by an iron fist by Mathieu Kérékou, was in the throes of a serious financial crisis, triggering a mobilization across sectors backed by the Catholic Church (students, teachers, hospital staff in Porto Novo, sugar industry workers, lawyers, taxi drivers, etc.). Shaken by the images of Ceausescu's fall in Romania, but also, and especially, by the 1988 Algerian riots, on December 26, 1989, Kérékou took the initiative of ending single party rule. Over the course of this process, he dropped Marxism-Leninism and convening a national conference bringing together the nation's main forces, which paved the way for an exemplary transition towards democracy (Vittin 1991, 93-116; Banégas 2003).

At the same time, the USSR played a key role in the negotiations that led to the end of civil wars in Angola, Mozambique, and Namibia. Moscow observed the process leading to the transition from Apartheid with keen interest. By gradually ending the Cold War, Gorbachev indirectly forced South Africa to redefine its international position and therefore to seek a way out of its isolation: ${ }^{16}$ President

15 SAPMO-Barch, DY 30/2435, Relation to Chile, Information for the Politburo of the Central Committee / Note on a conversation Honecker/Volonia Teitelboim, Member of the Political Commission and the Secretariat of the Central Committee of the Communist Party of Chile on February 2, 1989, 131.

16 Anti-Apartheid Movement, "Apartheid Economy in Crisis”, Report to the Annual General Meeting, November 1989, 5. https://www.aamarchives.org/archive/reports/ar28-report-to-the-agmoct-1988-oct-1989.html 
Botha, who had met with Mandela in the summer of 1989 to discuss the liberation of political prisoners, (see Mandela 1994, 479) was replaced in August by a man who was just as conservative, yet more of a pragmatist - Frederik de Klerk. By then, anti-Communism was no longer the cement of the Western bloc, and since 1988, an international public opinion had rallied around Anglican pastor Trevor Huddleston's Freedom at 70 initiative. South Africa was thus indirectly impacted by the "Gorbachev factor", as it witnessed the emergence of a political leader who organized the political transition process. In October 1989, de Klerk freed some political prisoners from the ANC. He went on to announce the end of Apartheid in his famous February 2, 1990 speech, heralding a new era, and claiming that 1989 would "go down in history as the year in which Stalinist Communism expired"17.

\section{The shared experience of a "gap in time"}

The year 1989 was not only a geopolitical shock whose multiple epicenters included the USSR. It was also a time when millions of individuals went through the historical experience of a "gap in time" (Arendt 1961), meaning the disarticulation between the space of experience and the horizon of expectation. This breach in historical time is characterized by the emergence of a disrupted temporality: both past and present are passed and give way to the unknown, to an uncertain future. In theater, this is called the experience of "dénouement" (Ruffel 2005), understood not as the end of history but as a time of transition and uncertainty.

A global history of 1989 should aim at inventorying and analyzing these temporal experiences lived by the actors: How did 1989 produce (or failed to do so) breaches in the space-time continuum in various places?

\subsection{A breach in historical time}

In his February 1989 conversation with Volonia Teitelboim, Erich Honecker painted a very positive picture of the state of international relations: "Ultimately, one can see that the world has followed a path allowing us to avoid nuclear cataclysm and that regional conflicts have been contained. On an international level,

17 Address by the State President De Klerk at the opening of the $2^{\text {nd }}$ session of the $9^{\text {th }}$ Parliament of the Republic of South Africa, 2 February 1990. 
there has been a shift from confrontation to cooperation between different social systems". 18

The "Gorbachev factor" contributed to the violent disruption of the Socialist temporality that had been in place in many countries for decades and to the acceleration of time. Within the Eastern bloc, over the course of 1989, multiple temporalities emerged, reflecting what Ernst Bloch termed "non-simultaneity" (1935, 82). This concept refers to the shattering or disarticulation of a society's historical continuum (the dominant historical time), resulting in the coexistence of temporalities. This sense of temporal disorientation was not an unprecedented phenomenon. It had already been perceptible at the European level at two historical junctures - the French Revolution and the interwar period - and described by authors such as Chateaubriand and Zweig.

Thus, a plural approach to time allows us to identify "temporal shifts", just as Jacques Revel identified what he called "scale shifts". These temporal shifts reflect a variety of modalities of action on time: stalling, delaying, adjourning, deferring, having people wait or hurry, precipitating, preempting, blindsiding, taking by surprise, taking action, etc. The ways in which historical actors accelerate or stall materialize in practices that they view as suited to the context and the situation. In other words, the actors, in politics and beyond, are not present in the same way in history in the making: "Not all people exist in the same Now. They only do so externally, through the fact that they can be seen today. But they are thereby not yet living at the same time with the others” (Bloch 1991 [1935], 97). Thus, a global history of 1989 should examine divergences among policy-makers regarding their relationships to historical time. Where some actors, beginning with Gorbachev, helped make historical time more fluid by supporting international convergence and co-operation processes between two antagonistic but increasingly interdependent civilizational systems, other leaders continued for months to conceive of their present within a bipolar international order. In April 1989, during a meeting with Honecker, Jorge Risquet, a member of the Cuban communist party's political bureau, lambasted US Secretary of State James Baker over a press agency dispatch that claimed he had "demanded the USSR bring down the Berlin Wall, abolish the Brezhnev doctrine, and suspend Cuban aid to Nicaragua”. ${ }^{19}$ Honecker responded

18 SAPMO-Barch, DY 30/2435, Relation to Chile, Information for the Politburo of the Central Committee/Note on a conversation Honecker/Volonia Teitelboim, Member of the Political Commission and the Secretariat of the Central Committee of the Communist Party of Chile on February 2, 1989, 131.

19 SAPMO-Barch, DY 30/2462, Relations to Cuba, Note on the conversation Honecker/Jorge Risquet, Member of the Politburo and Secretary of the Centralcommittee of the Communist Party of Cuba, 17 April 1989, 439. 
with irony: "Baker is demanding a lot at once". ${ }^{20}$ Some statesmen, including the East German leader and Castro, were incapable of looking at the present as something other than a stable time. They gradually dug themselves in deeper, denying the acceleration of time, stuck in their political myopia. In this "fluid conjuncture" (Dobry 1992), citizens began to take to the streets in dozens of thousands, rejecting official discourses that had become inaudible. Paradigmatic illustrations of this clash of temporalities were provided by sights such as Erich Honecker being visibly annoyed by East German youth chanting "Gorbi! Gorbi” as they marched down Unter den Linden on October 9,1989 or Nicolae Ceausescu booed by a Bucharest crowd on December 21, 1989. ${ }^{21}$

This simultaneity of non-simultaneities led to an increasingly widening gap between reformists and conservatives. This "breach in time" proved impossible to bridge for a number of political actors, who appeared to fall behind the times more and more, like Erich Honecker. As Bloch put it, "We will not therefore already try to seek any older sort where there is merely a backward one. Which is admittedly badly disposed to the today, but belongs to it” (1991 [1935], 104). Tracking these gaps, these divergences between the Soviet, Chinese, East German, Hungarian, and Polish positions raises a key question for the writing of global history - that of the "simultaneity of the non-simultaneous", or non-simultaneity.

\section{2 "The simultaneity of the non-simultaneous" (Bloch)}

The year 1989 can be analyzed as a clash of both representations and temporalities: the actors were no longer present in the same way in history in the making (see Droit 2019). There wasn't a single linear temporal level, but a mesh of relationships to different historical times. Gorbachev, Jaruzelski, Kérékou, Castro, or Honecker "did not exist in the same Now", Bloch (1991 [1935], 97) put it. The Cuban and East German leaders lived in a present characterized by a strictly bipolar order the "international class confrontation between socialism and imperialism". ${ }^{22}$ Within that framework, "the enemy" would resort to all kinds of strategies - such as the instrumentalization of Perestroika - to destabilize if not destroy the unity of the socialist camp, hence the call for socialist co-operation and solidarity.

20 SAPMO-Barch, DY 30/2462, Relations to Cuba, Note on the conversation Honecker/Jorge Risquet, Member of the Politburo and Secretary of the Centralcommittee of the Communist Party of Cuba, 17 April 1989, 439.

21 INA Archives, TV news hosted by Guillaume Durand, La Cinq, December 21,1989.

22 BStU, MfS, ZAIG 5461, 36. 
Mikhail Gorbachev's present, shared by the reformers in Hungary and Poland, was quite different: it was an open, multipolar world, in the process of a peaceful transition towards a politically democratic society. By 1989, the Communists no longer shared the same worldview on the present. This discordance, amplified by Gorbachev's withdrawal policy, was not necessarily internalized by Eastern European dissidents and Western leaders. In the afternoon of November 9, 1989, the West German chancellor met with Lech Wałesa and Bronislaw Geremek in Warsaw. They discussed the situation in the DDR: Walesa feared that the situation would develop "out of control" (BMI et al. 1988, 492-496) and believed that the East German authorities were going to mobilize the army to end the protests. He anticipated an outbreak of violence, with the 1981 Polish precedent in mind. At the very same time, on Moscow's Staraya Square, a short walk from the Kremlin, the CPSU's Politburo was convening. The order of the day was not the external Soviet Empire, but the fate of the USSR itself: to what extent should military force be used to preserve its territorial integrity? Ultimately, Gorbachev turned down the military option, instead calling for the formation of "a pan-Union consciousness" drawing on "mass media” support (Blanton et al. 2010, 578). ${ }^{23}$

In 1989, then, for a number of actors, time was quite literally broken: the guiding thread of stability and continuity - tradition, one might say - had been cut. Once state Communism collapsed in the East, the past no longer illuminated the future, and the mind of men wandered in obscurity, to paraphrase Tocqueville. Frédéric Bozo's work on François Mitterrand clearly showed that the French president feared this fluid geopolitical conjuncture would bring a "return to 1913" (Bozo 2005, 228-230). At the same time, such fears were shared by some American political scientists. In 1990, for instance, John Mearsheimer $(1990,52)$ argued that the end of the Cold War could increase the threat of a return of wars and major crises in Europe.

Pursuing the hypothesis of a global breach in time requires the production of multi-sited empirical studies. For a number of political actors in power, these fluid conjunctures had very practical effects on how they handled political crises, and on whether they committed or not to diplomatic processes like German reunification. Exploring these temporal questions is admittedly a difficult task (as it involves retracing these experiences of time in archives), but an innovative and necessary means of updating approaches to 1989.

23 Session of the CC CPSU Politburo, November 9, 1989, transcribed in Savranskaya et al. (2010, 578). 


\section{Rethinking 1989: the challenge of a critical, decentered history}

By 2009, as the twentieth anniversary of the fall of the Berlin Wall was celebrated, five years after the European Union was enlarged to former Eastern bloc countries, the year 1989 had been proclaimed a foundational element in the memory of the post-bipolar order, and canonized by numerous political actors and experts. Political commemorations, especially in Germany, constructed a heroic narrative, emphasizing the role of Eastern European civil societies and celebrating the victory of freedom over Soviet communism.

As in all political discourses on historical memory (Lagrou 2013, 101-119), this take on 1989 necessarily contained a kernel of truth. At the same time, it was attacked for political purposes by such "memory entrepreneurs" as the head of the PIS in Poland, Lech Kaczyński, or the leaders of the AfD in Germany, who took on this "Bastille of memory" to denounce what they perceived as flaws in the postCommunist transition, considered too soft or hijacked by West German elites (see Heurtaux and Pellen 2009).

This short-term memory of 1989 and its instrumentalization require historians to reconsider this historical object. Rethinking it in a global perspective should allow us to unveil the considerable potential of historiographical innovation inherent in this written form of history. Mindful of the intermingling of spatial and phenomenological dimensions, and of the differences in processes of dissemination and diffraction, this approach yields critical insights into this 'global event' while deconstructing the political uses of the memory of this "year without equal" (Grosser 2009, 14).

Historicizing 1989 as a global history requires a twofold research effort. On the one hand, unprecedented empirical studies must be undertaken, drawing on European, Arab, African, Latin American, and Asian archives. A new generation of global historians will have to go beyond rhetoric postures denouncing Eurocentrism and produce new studies implementing decentered approaches and accounting for the plurality of experiences. On the other hand, global history, while it does aim at "provincializing Europe”, in no way means rejecting European conceptual tools (Stanziani 2018). The first order of work is to examine how it is possibly to breathe new life into the analysis of 1989 from the margins and peripheries of the Western world. Different spatial and temporal scale shifts should be considered jointly: what happens globally can be understood from a local vantage point, in specific configurations, places of transit, interactions, and conflicts.

In effect, the shock wave of the "Gorbachev factor" was felt all around the world, and these forms of concomitance and regional discontinuities should be 
addressed. On a micro level, 1989 was a considerable collective and individual shock. This breach in everyday lives often came with the experience of disorientation, of a profound loss of socio-professional identity and democratic disenchantment. At the same time, we need to consider of the experience of 1989 in the margins and peripheries had gradually transformed Western Europe and the West as a whole. In that sense, the conceptual tool of "co-transformation" suggested by Philip Ther $(2014,279-305)$ in his history of neo-liberal Europe should be discussed and operationalized to measure its analytical benefits.

Another means of reconsidering the global dimensions of 1989 would be to take into account also the nostalgia produced in the West since the end of the Cold War. To some thinkers and international relations experts, the bipolar order, despite the balance of terror, was a period of global stability. Its demise has given way to an uncertain, changing international environment - between the rise of China, the resurgence of Russia, and the withdrawal of the US - which has in turn sparked nostalgia of the previous era.

Overall, 1989, as a possible prehistory of the conditions of our present, has again become a key object of reflection for the history of our immediate contemporary times.

\section{References}

Anti-Apartheid Movement. “Apartheid Economy in Crisis”. Report to the Annual General Meeting. (5 November 1989). https://www.aamarchives.org/archive/reports/ar28-report-tothe-agm-oct-1988-oct-1989.html (last access 07 June 2020).

Arendt, Hannah. Between Past and Future. New York: The Viking Press, 1961.

Banégas, Richard. La Démocratie à pas de caméléon. Transition et imaginaires politiques au Bénin. Paris: Karthala, 2003.

Bantigny, Ludivine, Boris Gobille, and Eugénia Palieraki. “Les ‘années 1968’ : circulations révolutionnaires". Monde(s) 11 (2017).

-.1968. De grands soirs en petits matins. Paris: Seuil, 2018.

Barancz, Stanisław. “Annus Mirabilis”. Salmagundi 85/86 (1990): 5-11.

Berend, Ivan T. and Bojan Bugaric. "Unfinished Europe: Transition from Communism to Democracy in Central and Eastern Europe”. Journal of Contemporary History 50.4 (2015): 768785.

Bertrand, Romain and Guillaume Calafat. "La micro-histoire globale: affaire(s) à suivre". Annales: Histoire, Sciences Sociales 73.1 (2018): 1-18.

Bispinck, Henrik, Jürgen Danyel, Hans H. Hertle, and Hermann Wentker. Eds. Aufstände im Ostblock: Zur Krisengeschichte des realen Sozialismus. Berlin: Links Verlag, 2004.

Bloch, Ernst. Heritage of our Times. Berkeley, Los Angeles: University of California Press, 1991 [1935].

Bösch, Frank. Zeitenwende 1979. Als die Welt von heute begann. Munich: Beck Verlag, 2019. 
Borodzej, Wlodzimierz. "Vom Warschauer Aufstand zum Runden Tisch. Politik und Gewalt in Polen 1944-1989”. 1989 und die Rolle der Gewalt. Ed. Martin Sabrow. Göttingen: Wallstein, 2012, 278-303.

Bozo, Frédéric. La fin de la guerre froide et l'unification allemande. De Yalta à Maastricht. Paris: Odile Jacob, 2005.

Brown, Archie. The Gorbachev Factor. Oxford: Oxford University Press, 1997.

Brown, Timothy S. "1968. Transnational and Global Perspectives". Docupedia-Zeitgeschichte (11 June 2012). http://docupedia.de/zg/1968?oldid=132775 (last access 26 March 2020).

-. Ministry for State Security (MfS), ZAIG 5461, 36.

Bundesministerium des Innern unter Mitwirkung des Bundesarchivs. Ed. Deutsche Einheit. Sonderedition aus den Akten des Bundeskanzleramtes 1989/90, 492-496. Munich: Oldenbourg, 1998, 492-496.

Chartier, Roger. "La conscience de la globalité”. Annales: Histoire, Sciences Sociales 56.1 (2001): 119-123.

Compagnon, Olivier and Caroline Moine. “Chili 1973, un événement mondial”. Monde(s) 8 (2015).

Conrad, Sebastian. What is Global History? Oxford: Princeton University Press, 2017.

Dahlmann, Ulf, Lydia Röder, and Ilse Wernitz. "Protestschreiben an die Botschaft der Volksrepublik China”. (4 June 1989). Archiv der Robert-Havemann-Gesellschaft. https://www.havemann-gesellschaft.de/04061989-protestschreiben-an-die-botschaftder-volksrepublik-china/ (26 March 2020).

Dahrendorf, Ralf. Reflections on the Revolution in Europe. London: Routledge, 2004.

Doering-Manteuffel, Anselm and Lutz Raphael. Eds. Nach dem Boom. Perspektiven auf die Zeitgeschichte seit 1970. Göttingen: Vandenhoeck \& Ruprecht, 2008.

Dakowska, Dorota. "1989". The Dictionary of Transnational History. Eds Akira Iriye and PierreYves Saunier. London: Palgrave Macmillan, 2009, 3-4.

Drayton, Richard and David Motadel. "Discussion: The Future of Global History". Journal of Global History 13.1 (2018): 1-21.

Droit, Emmanuel. “Les césures du temps présent. Approche comparée franco-allemande”. Atala 17 (2014): 167-181.

-. Les polices politiques du Bloc de l'Est. À la recherche de l'Internationale tchékiste 19551989. Paris: Gallimard, 2019.

Engel, Ulf, Frank Hadler, and Matthias Middell. Eds. 1989 in a global perspective. Leipzig: Leipziger Universitätsverlag, 2014.

Federal Commissioner for the Records of the State Security Service of the former German Democratic Republic [Der Bundesbeauftragte für die Unterlagen des Staatssicherheitsdienstes der ehemaligen DDR, BStU], Zentralarchiv (ZA), Hauptabteilung II, 26979.

Foundation Archives of the Political Parties and Mass Organisations of the GDR in the Federal Archives [Stiftung Archiv der Parteien und Massenorganisationen der DDR im Bundesarchiv], SAPMO-Barch. DY 30/2479. Vol. 4: 1984-1989, 355-364.

-. DY $30 / 2462,439$.

-. DY $30 / 2437$, Stenograph Record of the official meeting between the General Secretary of the Central Committee of the SED and President of the State Council of the GDR and the General Secretary of the Central Committee of the Chinese Communist Party and President of the State Council of the People's Republic of China, Zhao Ziyang, 8 June 1987, in Berlin, 17. 
-. DY 30/2435, Relationships to Chile, Information for the Political Bureau of the Central Comittee / Comment about a discussion between Honecker and Volonia Teitelboim, Member of the Political Commission and of the Secretariat of the Central Committee of the Chilean Communist Party, 2.2.1989, 131.

-. DY 30/2437, Bureau Honecker, Relationships to China, Short notice written by Gunter Schabowski to Honecker (he was in China at that time), 14 April 1989, 165.

-. DY 30/2462, Bureau Erich Honecker, Relationships to China, Notice about a discussion between Honecker and Jorge Risquet, Member of the Political Bureau and of the Secretariat of the Central Committee of the Cuban Communist Party, 17 April 1989.

Frank, Robert. “Émotions mondiales, internationales et transnationales 1822-1932”. Monde(s) 1 (2012): 47-70.

Fukuyama, Francis J. "The End of History". The National Interest 16 (1989): 3-18.

Garton Ash, Timothy. "Revolution in Hungary and Poland". The New York Review of Books (17 August 1989). https://www.nybooks.com/articles/1989/08/17/revolution-in-hungaryand-poland/ (26 March 2020).

“Goldene Neunziger?”. Die Zeit (5 January 1990). https://www.zeit.de/1990/02/goldeneneunziger (26 March 2020).

Grosser, Pierre. 1989. L'année où le monde a basculé. Paris: Perrin, 2009.

Gruzinski, Serge. Les quatre parties du monde. Histoire d'une mondialisation. Paris: La Martinière, 2004.

Gorbatchev, Mikhaïl. Mémoires. Monaco: Editions du Rocher, 1997.

Gorbachev, Mikhaïl. "Address by Mikhail Gorbachev at the UN General Assembly Session (Excerpts)". 7 December 1988. Wilson Center. History and Public Policy Program Digital Archive. https://digitalarchive.wilsoncenter.org/document/\%20116224\%20.pdf (26 March 2020).

Heurtaux, Jérôme and Cédric Pellen. Eds. 1989 à l'Est de l'Europe. Une mémoire controversée. La Tour d'Aigues: Éditions de l'Aube, 2009.

Holm, Andrej. Kommen. Gehen. Bleiben. Andrej Holm im Gespräch mit Samuel Stuhlpfarrer. Berlin: Mandelbaum Verlag, 2017.

INA Archives. TV news hosted by Guillaume Durand, La Cinq (21 December 1989).

Jian, Chen. "Tiananmen and the Fall of the Berlin Wall". The Fall of the Berlin Wall. The Revolutionary Legacy of 1989. Ed. Jeffrey A. Engel. Oxford: Oxford University Press, 2009, 96-131.

Kenney, Padraic. A Carnival of Revolutions: Central Europe 1989. Princeton: Princeton University Press, 2003.

- and Gerd-Rainer Horn. Eds. Transnational Moments of Change: 1945, 1968, 1989. Lanham: Rowman \& Littlefield, 2004.

Khlevniuk, Oleg. Master of the House. Stalin and His Inner Circle. New Haven: Yale University Press, 2008.

Klerk, Frederik Willem de. "Address by the state president, Mr FW de Klerk, DMS, at the opening of the second session of the ninth parliament of the Republic of South Africa, Cape Town". 2 February 1990. South African Government Information. https://web.archive.org/web/ 20041215042859/http://www.info.gov.za/speeches/1996/101348690.htm (26 March 2020).

Kotkin, Stephen and Tomasz Gross. Rok 1989. Koniec społeczeństwa nieobywatelskiego. Warsaw: Swiat Ksiazki, 2009.

Lagrou, Pieter. "De l'histoire du temps présent à l'histoire des autres. Comment une discipline devient complaisante”. Vingtième Siècle. Revue d'histoire 118 (2013): 101-119. 
Mandela, Nelson. Long Walk to Freedom: The Autobiography of Nelson Mandela. Boston: Little, Brown and Company, 1994.

Mark, James and Tobias Rupprecht. “Europe's '1989' in Global Context”. The Cambridge History of Communism. Vol. III: Endgames? Late Communism in Global Perspective, 1968 to the Present. Eds Juliane Fürst, Silvio Pons, and Mark Selden. Cambridge: Cambridge University Press, 2017, 224-249.

Maurel, Chloé. “Introduction: Pourquoi l'histoire globale?”. Cahiers d'histoire. Revue d'histoire critique 121 (2013): 13-19.

Mearsheimer, John. "Back to the Future: Instability in Europe after the Cold War". International Security 15.1 (1990): 5-56.

Middell, Matthias. "1989". The Oxford Handbook of the History of Communism. Ed. Stephen A. Smith. Oxford: Oxford University Press, 2015, 171-184.

Nora, Pierre. “L'événement monstre”. Communications 18 (1972): 162-172.

Osterhammel, Jürgen. La Transformation du monde. Une histoire globale du XIXe siècle. Paris: Nouveau Monde, 2017.

Postel-Vinay, Karoline. “Writing 1989: A World Narrative?”. 1989 as a Political World Event: Democracy, Europe and the New International System in the Age of Globalization. Ed. Jacques Rupnik. London: Routledge, 2014, 25-33.

Ruffel, Lionel. Le dénouement. Paris: Verdier, 2005.

Rupnik, Jacques. Ed. 1989 as a Political World Event: Democracy, Europe and the New International System in the Age of Globalization. London: Routledge, 2014.

-. "Le retour de l'histoire en Europe centrale". Vingtième Siècle. Revue d'histoire 36 (1992): $53-60$.

Sabrow, Martin. "Zäsuren in der Zeitgeschichte”. Docupedia-Zeitgeschichte. (3 June 2013). http://docupedia.de/zg/Zaesuren?oldid=125865 (26 March 2020).

-. 1989 und die Rolle der Gewalt. Göttingen: Wallstein, 2012.

Savranskaya, Svetlana, Thomas Blanton, and Vladislav Zubob. Eds. Masterpieces of History. The Peaceful End of the Cold War in Europe. Session of the CC CPSU Politburo, 9 November 1989. Budapest", note="New York: CEU Press, 2010, 1989.

Schäfer, Bernd. "Die DDR und die chinesische Lösung”. 1989 und die Rolle der Gewalt. Ed. Martin Sabrow. Göttingen: Wallstein Verlag, 2012, 153-172.

Siebold, Angela. "1989 und die Herausforderungen einer transnationalen, globalen Geschichte”. Zeitgeschichte-online (March 2019). https://zeitgeschichte-online.de/themen/1989und-die-herausforderungen-einer-transnationalen-globalen-geschichte (26 March 2020).

Spivak, Gayatri Chakravorty. Death of a Discipline, 71-102. The Wellek Library Lectures Series. New York: Columbia University Press, 2003, 71-102.

Stanziani, Alessandro. Eurocentrism and the Politcs of Global History. London: Palgrave, 2018.

Ther, Philipp. Die neue Ordnung auf dem alten Kontinent. Eine Geschichte des neoliberalen Europa. Frankfurt/Main: Suhrkamp, 2014.

Vittin, Théophile. "Bénin, du système Kérékou au renouveau démocratique”. États d'Afrique noire. Ed. Jean-François Médard. Paris: Karthala, 1991, 93-116.

Zakibi, Zhand P. “Central Government”. The Cambridge History of Russia. Vol. 2: Imperial Russia 1689-1917. Ed. Dominic Lieven. Cambridge: CUP, 2006, 429-448.

Zaremba, Marcin. Komunizm, legitymizacja, nacjonalizm: nacjonalistyczna legitymizacja władzy komunistycznej w Polsce. Warsaw: Trio, 2001. 